AGRICULTURE AND BIOLOGY JOURNAL OF NORTH AMERICA

ISSN Print: 2151-7517, ISSN Online: 2151-7525, doi:10.5251/abjna.2011.2.7.1053.1058

(C) 2011, ScienceHu $\beta$, http://www.scihub.org/ABJNA

\title{
Limnological assessment of effluents on invertebrates from Alaro River in Oluyole industrial area of Ibadan, Oyo State, Nigeria.
}

\author{
${ }^{1}$ A.J. Akinyeye, ${ }^{2}$ J.I. Komolafe, and ${ }^{1}$ T.G. Okorie \\ ${ }^{1}$ Department of Biological Sciences Igbinedion University, Okada, Edo State, \\ ${ }^{2}$ Biology Department Osun State College of Education, llesa, Osun State.
}

\begin{abstract}
A limnological assessment of the impact of industrial effluents from Oluyole industrial Area on Alaro stream and a pond, was carried out in August - November, 2002. The physico-chemical parameters and the heavy metal concentrations of the effluents were investigated to determine their effects on the water quantity. The analysis of mudcrab - Eurypanopaus adspersus; pouch snails - physa spp; pondweed - potamogeton spp; and banana sucker - Musa spp, showed that the tendency of heavy metal bioaccumulation or bioavailability may be on the increase if the value in the water continues to increase. The highest and lowest mean concentration $\left(\mathrm{mgkg}^{-1}\right)$ of heavy metals in the organisms ranged from; As (40) in pouch snail and (15) in mudcrab, Cd (45) in banana sucker and (20) in mudcrab.
\end{abstract}

Keywords: limnology, physico-chemical, effluent, bioaccumulation, heavy metal.

\section{INTRODUCTION}

The location of human settlements as well as the sitting of industries close to water bodies provides such benefits as: harbour facilities, water transportation, fishing and other socio-economic benefits. With the rapid expansion of the industrial sector and the increase in demand for consumer goods, occasioned by population growth and economic development in Nigeria, large quantities of wastes are being generated. Waterways now provide a cheap and effective medium of disposing these wastes. The major sources of heavy metal pollution have been identified as industrial and municipal wastes (Calabrase et al, 1977). Some of these heavy metal contaminants have been proven to have deleterious effects on aquatic organisms and cause ecological imbalance especially in the distribution and abundance of organisms. The greatest pollution problems Nigeria has ever experienced and is still going through is that of aquatic pollution (Sikoki and Kolo, 1992). During the dry season, the flow of some tropical rivers consists almost exclusively of effluents, due to reduction in the volume of water as a result of seasonality in the flow of rain runoff.

Bioaccumulation and internal distribution of a given metal depends on several factors, which include: the chemical form of the contaminants and its bioavailability, the taxon considered and the ambient water quality characteristics such as $\mathrm{pH}$ and hardness (Hare et al., 1991). One problem, which is particularly difficult to solve is the accumulation of these toxic substances - metals and biocides in aquatic environment. This has direct effects on the source of water supply, agricultural use of water and on fisheries. Fish have suffered greatly from the effects of heavy metals. Soliba and Kenzyz (1976) reported that heavy metals inhibit the hatching of fish eggs and poorer development of embryos. Kolo (1989) also noticed total absence of fish in Ogunpa river (Ibadan), in the areas which were heavily polluted with heavy metals, while the presence of copper was found to affect the composition of zooplanktons assemblage (Haven, 1994).

\section{MATERIAL AND METHODS}

Study Area: Ibadan the capital of Oyo State is the largest urban center in West Africa. Based on the 1991 provisional census data, it has a built up area of $240 \mathrm{~km}^{2}$ and a population of 1,991,367 (Ogbuagu, 1991). Oluyole Industrial Estate is one of the industrial layouts of Ibadan. It is located on latitude $7^{0} 19^{1} 10^{11} \mathrm{~N}-7^{0} 23^{1} 36^{11} \mathrm{~N}$ and longitude $3^{0} 50^{1} 33^{11} \mathrm{E}-$ $3^{0} 55^{1} 16^{11} \mathrm{E}$. It is about $1.5 \mathrm{~km}$ away from Mobil filling station along Ring Road - Challenge expressway in Ibadan Southwest Local Government Area.

The industries: SUMAL, 7UP, and INTERPACK are situated about $80 \mathrm{~m}$ away from Alaro stream - a tributary of RIVER Ona. ISO-GLASS is located about 250m away from the Alaro stream. SUMAL, 7UP, and INTERPACK, discharge their effluents collectively through a canal into Alaro stream, while ISO-GLASS 
discharges its effluents through an underground pipe which possibly joins Alaro stream somewhere further down stream. A small pound is situated about $4 \mathrm{~m}$ from ISO-GLASSS (Fig.1).

During the raining season, the stream is known to overflow some of its banks along its flow route. The water is more turbid in the raining season than dry season, possibly due to runoff and other discharges. The stream is characterized by pungent smell in the dry season and occasional complete dryness of the stream has been observed, most importantly during severe dryness or longer dry months. The bed of the stream consists of sand and gravels upstream, while sand, silts, gravels and rocks characterized the down stream. Refuse dumps with human faeces and farmlands bordered the sides of the downstream and farmland upstream. The pond on the other hand is stagnant pool of clear or transparent water, which overflows its banks and flows on the road during the raining season. The pond is characterized by vegetation growing round it, and pondweeds growing in some portions of the pond. Nefarious odour oozes out occasionally from the pond. The bed of the pond consists of sand, silt and generally muddy darkcoloured sediment with decaying vegetable matter. Total dryness of the pond was observed during the course of this study.

The crabs were collected about $(1 \mathrm{~m})$ at the side of the stream, the banana stem fell into the stream while the pondweed had its root at the side and bottom of the pond with the stems and leaves above the water. Snails were found attached to the stem and leaves of the pondweed.

The sampling sites are:

- $\quad$ Sites A, C and D - represent the direct effluents collections from ISO- GLASS, 7UP, and SUMAL respectively.

- $\quad$ Site E - mid down stream, 15m away, from the point at which effluent enters Alaro stream

- $\quad$ Sites F - down stream.15m away from site $\mathrm{E}$.

- $\quad$ Sites $G$ - upstream, $30 \mathrm{~m}$ away from the point which effluent enters Alaro stream. It serves as a control site for the stream.

- $\quad$ State $B-$ a pond which is about $4 \mathrm{~m}$ from site $A$.

Analysis of metals in effluents and water: A representative of each of well-mixed sample $(100 \mathrm{ml})$ was transferred into a beaker and $5 \mathrm{ml}$ of concentrated $\mathrm{HNO}_{3}$ was added.

The solution was evaporated to near dryness on a hot plate, making sure that the sample did not boil. Heating was continued with addition of acid, until digestion was completed. (Light coloured residue obtained). $2 \mathrm{ml}$ concentrated $\mathrm{HNO}_{3}$ was added to dissolve the residue. The residue was washed with distilled water and filtered to remove silicates and other insoluble materials. The volume of solution was adjusted to $100 \mathrm{ml}$ in a volumetric flask. A sample solution and blank sample were analyzed for total heavy metals using BUCK 200 Atomic Absorption Spectrophotometer from the institute of Agricultural Research and Training, (IAR\&T) Moore Plantation, Apata, Ibadan.

Analysis of metals in organisms: The organisms collected were each dried in an oven (conventional hot air oven and Mufthefurnace size 2 Gallen Komp Model) at $105^{\circ} \mathrm{C}$. Each organism was later grounded to powder and put in a desicator. $\mathrm{HNO}_{3}$ and $\mathrm{HClO}_{4}$ of $2: 1$ were added to $2 \mathrm{~g}$ of the powder of each organism to digest it. The resultant residues were each dissolved in $10 \mathrm{ml}$ hydrochloric acid diluted to $100 \mathrm{ml}$ of distilled water. The solution from each organism was used for heavy metal analyses using the AAS (APHA, 1995).

\section{RESULTSIDISCUSSION}

Non-metal and metal concentration in the organisms: The concentrations of non and trace metals analyzed in the organisms in October and November, gave the lowest and the highest values as follow (Table 1): $K\left(1615 \mathrm{mgkg}^{-1}\right)$ in snails at site $B$ and $8925 \mathrm{mgkg}^{-1}$ in banana sucker at site $\mathrm{F}$; $\mathrm{Na}$ (540 $\mathrm{mgkg}^{-1}$ ) in snails and pondweed both in site $B$, and $870 \mathrm{mgkg}^{-1}$ in banana sucker at site $\mathrm{F}$; Ca $(2175$ $\mathrm{mgkg}^{-1}$ ) in snails at $B$ and $8614 \mathrm{mgkg}^{-1}$ in banana sucker at site $\mathrm{F} ; \mathrm{Mg}\left(35 \mathrm{mgkg}^{-1}\right)$ in pondweed, and 50 $\mathrm{mgkg}^{-1}$ in snails both in site $\mathrm{B} ; \mathrm{PO}_{4}\left(60 \mathrm{mgkg}^{-1}\right)$ in crabs at site $F$ and $G$, and $70 \mathrm{mgkg}^{-1}$ in banana sucker and pondweed in sites $F$ and $B$ respectively; $\mathrm{Mn}\left(30 \mathrm{mgkg}^{-1}\right)$ in crab at site $\mathrm{G}$, and $75 \mathrm{mgkg}^{-1}$ in pondweed in site $\mathrm{B}$; $\mathrm{SO}_{4}\left(45 \mathrm{mgkg}^{-1}\right)$ in banana sucker at site $F$, and $70 \mathrm{mgkg}^{-1}$ in crab and pondweed in sites $F$ and $B$ respectively; $F e\left(45 \mathrm{mgkg}^{-}\right.$ ${ }^{1}$ ) in pondweed, and $65 \mathrm{mgkg}^{-1}$ in snails both in site B (Table 1) 
Agric. Biol. J. N. Am., 2011, 2(7): 1053-1058

Table 1 Concentration of (heavy, trace and non metals) obtained from organisms surrounding (About $1 \mathrm{~m}$ ) Alaro stream and in a pond in October-November

\begin{tabular}{|c|c|c|c|c|c|c|}
\hline \multirow[b]{3}{*}{ Parameters } & \multirow[b]{3}{*}{ Months } & \multirow{2}{*}{\multicolumn{2}{|c|}{ POND B (mgkg $\left.{ }^{-1}\right)$}} & \multicolumn{3}{|c|}{ ALARO STREAM } \\
\hline & & & & \multicolumn{2}{|c|}{$\mathrm{F}\left(\mathrm{mgkg}^{-1}\right)$} & \multirow{2}{*}{$\frac{\mathrm{G}\left(\mathrm{mgkg}^{-1}\right)}{\mathrm{Crab}}$} \\
\hline & & Snail & Pondweed & $\begin{array}{l}\text { Banana } \\
\text { sucker }\end{array}$ & Crab & \\
\hline \multirow[t]{2}{*}{ As } & Oct & 40 & 30 & 30 & 25 & 15 \\
\hline & Nov & 40 & 35 & 35 & 28 & 15 \\
\hline \multirow[t]{2}{*}{$\mathrm{Cd}$} & Oct & 40 & 35 & 40 & 40 & 20 \\
\hline & Nov & 40 & 35 & 45 & 44 & 27 \\
\hline \multirow[t]{2}{*}{$\mathrm{Cu}$} & Oct & 60 & 65 & 45 & 65 & 60 \\
\hline & Nov & 60 & 60 & 50 & 67 & 60 \\
\hline \multirow[t]{2}{*}{$\mathrm{Pb}$} & Oct & 40 & 35 & 40 & 40 & 28 \\
\hline & Nov & 50 & 40 & 45 & 42 & 30 \\
\hline \multirow[t]{2}{*}{$\mathrm{Hg}$} & Oct & 35 & 25 & 30 & 28 & 18 \\
\hline & Nov & 35 & 30 & 35 & 28 & 20 \\
\hline \multirow[t]{2}{*}{$\mathrm{Ni}$} & Oct & 50 & 55 & 50 & 60 & 55 \\
\hline & Nov & 50 & 55 & 55 & 65 & 60 \\
\hline \multirow[t]{2}{*}{$\mathrm{Zn}$} & Oct & 50 & 53 & 45 & 63 & 60 \\
\hline & Nov & 55 & 55 & 50 & 70 & 60 \\
\hline \multirow[t]{2}{*}{$\mathrm{K}$} & Oct & 1615 & 7315 & 8925 & 2470 & 2456 \\
\hline & Nov & 1750 & 8500 & 8900 & 2530 & 2480 \\
\hline \multirow[t]{2}{*}{$\mathrm{Na}$} & Oct & 540 & 540 & 720 & 720 & 705 \\
\hline & Nov & 550 & 555 & 850 & 870 & 785 \\
\hline \multirow[t]{2}{*}{$\mathrm{Ca}$} & Oct & 2175 & 2847 & 8394 & 5872 & 5747 \\
\hline & Nov & 2365 & 3032 & 8614 & 5897 & 5792 \\
\hline \multirow[t]{2}{*}{$\mathrm{Mg}$} & Oct & 40 & 35 & 40 & 40 & 40 \\
\hline & Nov & 50 & 40 & 40 & 42 & 40 \\
\hline \multirow[t]{2}{*}{$\mathrm{PO}_{4}$} & Oct & 65 & 70 & 70 & 60 & 60 \\
\hline & Nov & 65 & 68 & 70 & 65 & 60 \\
\hline \multirow[t]{2}{*}{$\mathrm{So}_{4}$} & Oct & 60 & 65 & 45 & 65 & 60 \\
\hline & Nov & 50 & 70 & 50 & 70 & 65 \\
\hline \multirow[t]{2}{*}{$\mathrm{Cr}$} & Oct & 38 & 30 & 35 & 30 & 19 \\
\hline & Nov & 40 & 35 & 40 & 35 & 48 \\
\hline \multirow[t]{2}{*}{$\mathrm{Mn}$} & Oct & 60 & 70 & 55 & 50 & 30 \\
\hline & Nov & 60 & 75 & 60 & 55 & 48 \\
\hline \multirow[t]{2}{*}{$\mathrm{Fe}$} & Oct & 50 & 45 & 50 & 50 & 50 \\
\hline & Nov & 65 & 50 & 55 & 55 & 50 \\
\hline
\end{tabular}

Heavy metal studies in the organisms: The concentration of heavy metal analysis carried in the macro fauna and flora (Pouch snail - Physa spp; pondweed potamogeton spp; mud crab Eurypanopeus adspersus and banana sucker Musa spp. of the study sites in October and November are as follow: As $\left(15 \mathrm{mgkg}^{-1}\right)$ in crab at site $G$ and 40 $\mathrm{mgkg}^{-1}$ in snails at site B; Cd $\left(20 \mathrm{mgkg}^{-1}\right)$ in crab in site $\mathrm{G}$ and $45 \mathrm{mgkg}^{-1}$ in banana sucker in site $\mathrm{F}$; $\mathrm{Cu}$ ranged between $45 \mathrm{mgkg}^{-1}$ sucker and $67 \mathrm{mgkg}^{-1}$ in crab both in site $\mathrm{F}$; $\mathrm{Pb}$ ranged between $28 \mathrm{mgkg}^{-1}$ in crab in site $\mathrm{G}$ and $50 \mathrm{mgkg}^{-1}$ in snails in site $\mathrm{B}$; $\mathrm{Hg}$ $\left(18 \mathrm{mgkg}^{-1}\right)$ in crab in site $\mathrm{G}$ and $35 \mathrm{mgkg}^{-1}$ Snail and banana sucker in sites $\mathrm{B}$ and $\mathrm{F}$ respectively; $\mathrm{Ni}$ ranged between $50 \mathrm{mgkg}^{-1}$ in snails in site $B$ and banana sucker in site $\mathrm{F}$, and $65 \mathrm{mgkg}^{-1}$ in crab in site $\mathrm{F}$; $\mathrm{Zn}$ ranged between $45 \mathrm{mgkg}^{-1}$ in banana sucker and $70 \mathrm{mgkg}^{-1} \mathrm{crab}$ both in site $\mathrm{F}$; $\mathrm{Cr}$ ranged between $19 \mathrm{mgkg}^{-1}$ and $48 \mathrm{mgkg}^{-1}$ both in crab in site G (Table 1). These values represent the lowest and the highest concentration of heavy metals obtained in the organisms. 
The high concentration of heavy trace and nonmetals in organisms (which were far above the concentration in the water and sediments) showed that bioaccumulation must have occurred in the organisms. The concentration of heavy metals in the crabs in site $F$ was higher than that of site $G$. This simply could be as a result of the presence of effluent in site $\mathrm{F}$ (Table 1).

Copper - $\mathrm{Cu}$ has been shown to be a normal constituents and integral part of almost all crustacean species, and it is essential for their heamolymph oxygen transport protein (Senkebeli and Wriston, 1985; Adam et al., 1981; Bryan, 1967). Excessive tissue bioaccumulation of copper was found to cause a copper concentration dependent loss of osmoregulation and increase in oxygen consumption in green crab, carcinus maenas and rock crab Cancer irroratus (Thurberg et al; 1973).

Zinc This has been found to be an essential component in crustacean species, stabilizing the quaternary structure of haemocyanin (Mathis and Cumming, 1973), and also known to act as a cofactor in many enzyme systems, including carbonic anhydrase which is involved in ecdysis (Senkebeil and Wriston, 1985). However, Zn concentration > $750 \mu \mathrm{gl}^{-1}$ are known to inhibit acid phosphate and depress growth rate in algae, Selanatrum capricrnutum (Bartlett and Rabe, 1974).

Alikhan and Storch (1990) ascertained that nickel is required by isopods to sustain both muscular and neural action potential, while low dietary nickel concentrations have adverse effect on the metabolic regulator ability of the hepatopancreas of the terresterial isopad Oniscus asellus. Increase in cadmium contents in the tissues were found to cause elevation in serum osmolality in Carcinus meanas, and a depression of gill tissues oxygen consumption rate in carinus means, cancer irrotatus and Eurypanopeus adsperus (Thurberg et al., 1973).

Poor crop growth has been found to be associated with avalabilty of arsenic in soil (Woolsen, (1975); Friberg et al., (1977) stated that most metals may not affect the growth of plants but they can cause health hazard when human and animal consume these plants. There is danger then for the health of individual consuming the water or organisms in these sites (pond and stream). Fowler and Unlu (1978) then concluded that factors such as temperature, salinity, oxygen content, metal concentrations, age and especially frequency of molting in some organisms, modify the rate of metal accumulation and retention in organisms.

Heavy metal studies in the surface water and Effluents: The lowest and the highest range of heavy metal concentrations recorded in the surface water and the effluents, from August-November (Table 2) were:

Arsenic (As) - Arsenic ranged between 0.40 and 1.60 $\mathrm{Mgl}^{-1}$ in site $\mathrm{E}$ and $\mathrm{C}$ in the months of November and October respectively. As showed a perfect negative significant correlation with $\mathrm{Cu}$ and $\mathrm{Ca}(r=-1.00$, $p<0.05)$ respectively at site $E$. Cadmium (Cd) Ranged from $0.65-1.60 \mathrm{mgl}^{-1}$ in site $A$ and $C$ respectively in the most of month of October. $\mathrm{Cd}$ showed a strong negative significant correlation with $\mathrm{Ni}(r=-0.92, p>0.05)$, and with $\mathrm{Zn}(r=-0.89, p=0.05)$ in site $\mathrm{E}$.

Copper $(\mathrm{Cu})$ - This ranged between $1.00 \mathrm{Mgl}^{-1}$ in site $G$ and $11.60 \mathrm{Mgl}^{-1}$ in site $D$ in the months of August and November respectively. A strong negative significant correlation of $\mathrm{Cu}$ with $\mathrm{Pb}(\mathrm{r}=-$ $0.93, p<0.05$ ) was obtained in site $G$.

Lead $(\mathrm{Pb})$ - Lead concentrations ranged between $0.50 \mathrm{Mgl}^{-1}$ and $1.60 \mathrm{Mgl}^{-1}$ at site $\mathrm{D}, \mathrm{E}$ and $\mathrm{C}$, in the months of November and October respectively. $\mathrm{Pb}$ had a perfect negative significant correlation with $\mathrm{PO}_{4}$ and TSS $(r=-1.00, \mathrm{P}<0.05)$ respectively at sites E.

Mercury $(\mathrm{Hg})$ - ranged between $0.40 \mathrm{Mgl}^{-1}$ in site $\mathrm{D}$ and $1.63 \mathrm{Mgl}^{-1}$ in site $\mathrm{C}$ in October and November respectively. A strong negative non-significant correlation of $\mathrm{Hg}$ with $\mathrm{Ca}(r=-0.84, \mathrm{P}<0.05)$ was obtained in site $\mathrm{E}$.

Nickel (Ni) - Nickel concentration in the samples ranged between $0.40 \mathrm{Mgl}^{-1}$ in site $E$ and $2.00 \mathrm{Mgl}^{-1}$ in site $\mathrm{F}$ in November. A strong positive non-significant correlation of $\mathrm{Ni}$ with TDS $(r=0.88, p>0.05)$ was obtained in site $\mathrm{G}$.

Zinc $(\mathrm{Zn})$ - ranged between $0.10 \mathrm{Mgl}^{-1}$ and $2.20 \mathrm{Mgl}^{-}$ 1 in site $E$ and $D$ respectively in the month of November. Zinc showed a strong negative significant correlation with $\mathrm{K}(\mathrm{r}=-0.92, \mathrm{p}<0.05)$; with alkalinity $(r=-0.97, \quad p<0.05)$ at site $E$. showed monthly comparison of concentration of heavy metal in the surface water and the effluents. 
Agric. Biol. J. N. Am., 2011, 2(7): 1053-1058

Table 2: $\quad$ Heavy metal concentration of the effluents, Alaro stream, and a pond in August-November

\begin{tabular}{|c|c|c|c|c|c|c|c|c|}
\hline \multirow[b]{2}{*}{$\begin{array}{c}\text { Parameters } \\
\left(\mathrm{Mgl}^{-1}\right)\end{array}$} & \multirow[b]{2}{*}{ Month } & \multicolumn{2}{|c|}{ Effluent Pond } & \multicolumn{2}{|l|}{ Effluent } & \multicolumn{3}{|c|}{ Alaro stream } \\
\hline & & $A\left(M g l^{-1}\right)$ & $\mathrm{B}\left(\mathrm{Mgl}^{-1}\right)$ & $\mathrm{C}\left(\mathrm{Mgl}^{-1}\right)$ & $\mathrm{D}\left(\mathrm{Mgl}^{-1}\right)$ & $E\left(\mathrm{Mgl}^{-1}\right)$ & $F\left(\mathrm{Mgl}^{-1}\right)$ & $\mathbf{G}\left(\mathrm{Mgl}^{-1}\right)$ \\
\hline $\begin{array}{c}\text { ARSENIC } \\
\text { (As) }\end{array}$ & $\begin{array}{l}\text { AUG } \\
\text { SEP } \\
\text { OCT } \\
\text { NOV }\end{array}$ & $\begin{array}{l}1.20 \\
1.12 \\
0.72 \\
-\end{array}$ & $\begin{array}{l}0.80 \\
0.95 \\
0.80 \\
-\end{array}$ & $\begin{array}{l}1.42 \\
1.40 \\
1.60 \\
1.10\end{array}$ & $\begin{array}{l}1.05 \\
1.02 \\
0.83 \\
1.20\end{array}$ & $\begin{array}{l}1.00 \\
1.00 \\
0.85 \\
0.40\end{array}$ & $\begin{array}{l}1.20 \\
1.24 \\
0.80 \\
1.40\end{array}$ & $\begin{array}{l}0.80 \\
0.80 \\
0.92 \\
1.00\end{array}$ \\
\hline $\begin{array}{l}\text { CADMIUM } \\
\text { (Cd) }\end{array}$ & $\begin{array}{l}\text { AUG } \\
\text { SEP } \\
\text { OCT } \\
\text { NOV }\end{array}$ & $\begin{array}{l}1.00 \\
1.15 \\
0.65 \\
-\end{array}$ & $\begin{array}{l}0.80 \\
0.93 \\
0.70 \\
-\end{array}$ & $\begin{array}{l}1.44 \\
1.43 \\
1.60 \\
1.30\end{array}$ & $\begin{array}{l}1.20 \\
1.00 \\
0.90 \\
0.80\end{array}$ & $\begin{array}{l}0.90 \\
1.00 \\
0.70 \\
1.40\end{array}$ & $\begin{array}{l}1.20 \\
1.20 \\
0.80 \\
1.20\end{array}$ & $\begin{array}{l}0.86 \\
0.85 \\
0.87 \\
0.80\end{array}$ \\
\hline $\begin{array}{c}\text { COPPER } \\
\text { (Cu) }\end{array}$ & $\begin{array}{l}\text { AUG } \\
\text { SEP } \\
\text { OCT } \\
\text { NOV }\end{array}$ & $\begin{array}{l}1.20 \\
1.40 \\
2.60 \\
-\end{array}$ & $\begin{array}{l}2.20 \\
1.28 \\
2.40 \\
-\end{array}$ & $\begin{array}{l}1.42 \\
1.60 \\
3.60 \\
7.40\end{array}$ & $\begin{array}{l}1.40 \\
1.50 \\
2.80 \\
11.60\end{array}$ & $\begin{array}{l}1.20 \\
1.23 \\
2.60 \\
7.60\end{array}$ & $\begin{array}{l}1.80 \\
1.60 \\
2.40 \\
0.40\end{array}$ & $\begin{array}{l}1.00 \\
1.10 \\
2.60 \\
8.20\end{array}$ \\
\hline $\begin{array}{l}\text { LEAD } \\
(\mathrm{Pb})\end{array}$ & $\begin{array}{l}\text { AUG } \\
\text { SEP } \\
\text { OCT } \\
\text { NOV }\end{array}$ & $\begin{array}{l}1.18 \\
1.15 \\
0.70 \\
-\end{array}$ & $\begin{array}{l}0.84 \\
0.98 \\
0.80 \\
-\end{array}$ & $\begin{array}{l}1.38 \\
1.43 \\
1.60 \\
0.75\end{array}$ & $\begin{array}{l}1.00 \\
1.10 \\
0.80 \\
0.50\end{array}$ & $\begin{array}{l}1.20 \\
1.17 \\
0.80 \\
0.80\end{array}$ & $\begin{array}{l}1.20 \\
1.20 \\
0.80 \\
0.70\end{array}$ & $\begin{array}{l}0.85 \\
0.83 \\
0.90 \\
0.50\end{array}$ \\
\hline $\begin{array}{l}\text { MERCURY } \\
(\mathrm{Hg})\end{array}$ & $\begin{array}{l}\text { AUG } \\
\text { SEP } \\
\text { OCT } \\
\text { NOV }\end{array}$ & $\begin{array}{l}1.20 \\
1.19 \\
0.63 \\
-\end{array}$ & $\begin{array}{l}0.80 \\
1.15 \\
0.65 \\
-\end{array}$ & $\begin{array}{l}1.42 \\
1.45 \\
1.63 \\
0.71\end{array}$ & $\begin{array}{l}1.05 \\
1.15 \\
0.65 \\
0.40\end{array}$ & $\begin{array}{l}1.00 \\
1.06 \\
0.83 \\
0.80\end{array}$ & $\begin{array}{l}1.26 \\
1.28 \\
0.75 \\
0.73\end{array}$ & $\begin{array}{l}0.80 \\
0.87 \\
0.80 \\
0.50\end{array}$ \\
\hline $\begin{array}{l}\text { NIKEL } \\
(\mathrm{Ni})\end{array}$ & $\begin{array}{l}\text { AUG } \\
\text { SEP } \\
\text { OCT } \\
\text { NOV }\end{array}$ & $\begin{array}{l}1.20 \\
1.30 \\
1.23 \\
-\end{array}$ & $\begin{array}{l}1.20 \\
1.20 \\
1.20 \\
-\end{array}$ & $\begin{array}{l}1.40 \\
1.60 \\
1.81 \\
1.40\end{array}$ & $\begin{array}{l}1.30 \\
1.40 \\
1.20 \\
1.40\end{array}$ & $\begin{array}{l}1.20 \\
1.20 \\
1.23 \\
0.40\end{array}$ & $\begin{array}{l}1.30 \\
1.50 \\
1.20 \\
2.00\end{array}$ & $\begin{array}{l}1.00 \\
0.90 \\
1.20 \\
1.60\end{array}$ \\
\hline $\begin{array}{l}\text { ZINC } \\
(\mathrm{Zn})\end{array}$ & $\begin{array}{l}\text { AUG } \\
\text { SEP } \\
\text { OCT } \\
\text { NOV }\end{array}$ & $\begin{array}{l}1.20 \\
1.38 \\
1.21 \\
-\end{array}$ & $\begin{array}{l}1.40 \\
1.25 \\
1.22 \\
-\end{array}$ & $\begin{array}{l}1.50 \\
1.62 \\
1.80 \\
0.25\end{array}$ & $\begin{array}{l}1.40 \\
1.42 \\
1.19 \\
2.20\end{array}$ & $\begin{array}{l}1.25 \\
1.23 \\
1.20 \\
0.10\end{array}$ & $\begin{array}{l}1.75 \\
1.55 \\
1.20 \\
0.30\end{array}$ & $\begin{array}{l}1.20 \\
1.00 \\
1.22 \\
0.20\end{array}$ \\
\hline
\end{tabular}

Heavy metal studies in the surface water and the effluent

The average heavy metal range in all the sites was above FEPA and WHO standard. Though, moderately low values were obtained in site $G$ (which was devoid of the effluents). Anthropogenic sources may have contributed to occasional high values recorded in this sites (Table 2). The high concentration of heavy metals in the effluent sites than the stream and the pond, may imply that metal levels in the water depend on the contents of effluents discharging or entering the water (stream and pond).

\section{REFERNCES}

Adams,E., Simkiss, K and Taylor,M. (1981). Metal ion metabolism in the moulting crayfish Austropotamobius pallipes. Camp Biochem. Physiol. 72A, 73-76.
Ademoroti, C.M.A. (1996). Environmental Chemistry and Toxicology. Follidex press Ltd. Ibadan. Pp 215.

Alikhan, M. A. and storch, V. (1990). Copper and nickel uptake and accumulation, and their effects on redox and electrical potentials of hepatopancreatic cells of Oniscuis asellus (porcellionidae, Isopoda). Can. J. Zool, 68, 651-655.

APHA/AWWA/WEF, (1995). Standard Methods for Examination of waste and wastewater $.19^{\text {th }}$ Edition.

Barlett, L., F. and Funk, W. H. (1974). Effects of copper, zinc and cadmium on Selenastrum copricornutum. Wat. Res. 8, 179.

Bryan, G. W. (1967). Zinc regulation in the freshwater crayfish (including some comparative copper analyses). J. Exp. Biol. 46, 281296. 
Bryan, G. W. (1976). Heavy metals contamination in the sea. In Marine Pollution (Edited by Johnstone, R) Academic Press London. 185-30.2pp.

Bryan, V., Newbery, D. M., McLusky, D. S. and Campbell, R. (1985).Effect of temperature and salinity on the toxicity of arsenic to Three estuarine invertebrate (Corophum Volutator, Macona Baltica, Tubifex castatus). Mar. Ercol. Prog. Ser. 24:129-137.

Calabrese, A., Maclnnes, J. R., Nelson, D. A and Miller, J E. (1977). Mar. Biol. 41, 179pp.

FEPA, (1991). Guidelines and Standards for Environmental pollution Control in Nigeria.

Fowler, S. W. and Unlu, M. Y. (1978). Factors affecting bioaccumulation and elimination of arsenic in the shrimp Lysmata seticaudata. Chemospere 9; 711 720.

Friberg, L. and Lener, J. (1986). Handbook of the Toxicology of metals. Vol 11. Specific metals, Elsevier, New York. 446461.

Hare, I, Tessier, A and Campbell, P. G. C. (1991). Trace element distributions in aquatic insects: Variations among genera,Elements and lakes. Can. J. Fish. Aquat. Sci. 48, 1481 - 1491.

Havens, K. E. (1994). Structural and functional responses of a freshwater plankton community to acute copper stress. Environmental pollution 86: $259-266$.

Ikporukpo, E. (1994) impacts of domestic and industrial effluents on River Odo Ona at Apata - Challenge Odo Ona area of Ibadan. An M. Sc. Thesis, university of ibadan, Nigeria. 99pp.

Kolo, R. J. (1989). A limnological assessment of Ogunpa River, Ibadan, Nigeria. M.Sc. Thesis, University of Ibadan.
Margalef, R. (1961). Communication of structure in planktonic population. Limnology and Oceanography 6: $124-128$.

Mathis, B. J. and Cummings, T. F. (1973). Selected metals in river sediments, water and animals, J. Wat. Pollut. 45: $1573-1583$.

Ogbuagu, H.D. (1999). Physico-chemical characterization of brewery effluent and its toxicity on the developmental stage in Baufo regularis and benthopelagic organism. An M.Sc. Thesis, University of ibadan, Nigeria.

Podemski, C.L. (1999).Cumulative effects of multiple effluents and low dissolved oxygen stressors on may flies at cold temperatures. Canadian Journal of Fish and Aquatic Science 59 (9) : 1624 - 1630.

Senkebeil, E. G. and Wriston, J. C. (1981). Haemocyanin sythesis in the American Lobster Homarus americanus. Comp. Biochem. Physiol. 63B, 163-171.

Sikoki, F. D. and Kolo, R. J. (1992). Perspectives in water pollution and their implication for conservation of aguatic resources. Paper presented at the National Conference on the conservation of Aquatic Resources (Calabar, Nigeria May 11 - 14, 1992).

Thurberg, F. P., Dawson, M. A. and Collier, R. S. (1973). Effects of copper and cadmium on osmo-regulation and oxygen consumption in two species of estuarine crabs. Mar. Biol. 23, 171- 175.

WHO (1984). Guidelines for drinking water quality 335p.

Woolson, E. A. (Ed.). [1975]. Arsenical pesticides. Amer. Chem. Soc.Symp. Ser. 7. 176pp. 